\title{
KEPERCAYAAN DAN PERLAKUAN MASYARAKAT BANJAR TERHADAP JIMAT-JIMAT PENOLAK PENYAKIT
}

\author{
Arni \\ Fakultas Ushuluddin dan Humaniora \\ IAIN Antasari Banjarmasin \\ Diterima tanggal 3 Januari 2016 / Disetujui tanggal 15 Maret 2016
}

\begin{abstract}
:
This study is an important part of exploring on local valuable object development related to belief and treatment of Banjarese society in using amulets for medication. Amulets or assortment magic power stuffs are Sarigading fabric, Kalimbutuban, Samban, Kuwari, Caping, Buyu and Sawan bracelets, rings, and Gelang barajah (a bracelet with a special mystical writing on it), Picis, Sisik. Tenggiling (Fur's a hedgehog), baju and saputangan berajah (clothes and handkerchief with a special mystical writing on it), etc. Banjares society uses the entire amulets are for therapy medium because they have a kinship relationship with the unseen people. That is there is one of the member of family has twin brother or sister when she or he was born, but one of them was gone or invisible (unseen). In addition, it is caused that they feel having a genealogy relationship with former kings in the past. Another reason why they use the amulets is because they have a kinship relationship with crocodile incarnation. This circumstance compels them to use the amulets. These belief and treatment of most Banjarese society on the amulets are believed to be used as a medium of medication for illness which cannot be cured by medic. The amulets are worned on head, neck, shoulder, arm and finger. They can be tied on waist or they are worned as usual clothes, trousers and sarung. Before the amulets use for therapy, some of them are usually scented on kemenyan (burned incense), sometimes there are also Jasmine and Cananga flowers. This magic therapy is an implementation of life style which is completely mystical magic, as well as strong fanaticism on the instinct of ancestral. Medication through the amulets or the magic power stuffs are a primitive culture which common known as dynamism, animism, fetishism, and Totemism.
\end{abstract}

Kata kunci: Kepercayaan, Jimat, Terapi, Masyarakat Banjar

\section{Pendahuluan}

Islam yang ideal dan benar adalah sebagaimana yang dicontohkan atau diajarkan oleh Nabi Muhammad Saw., hal inilah yang disebut Islam Normatif. Sedangkan Islam seperti yang senyatanya terjadi dalam masyarakat disebut Islam Historis, Islam Kontekstual atau juga bisa disebut Islam Empiris. Yakni Islam dalam kenyataan, yang dapat diamati, benar-benar terjadi, benar-benar diamalkan oleh manusia atau masyarakat, terkait atau yang disesuaikan dengan kondisi ruang dan waktu, kapan dan di mana Islam diamalkan oleh manusia atau masyarakat tersebut. ${ }^{1}$ Jadi, Islam yang ada di Kalimantan Selatan sekarang, yang dalam kenyataan terjadi di masyarakatnya secara umum tergolong pada kategori Islam Historis, Islam Kontekstual atau bisa juga dikatakan Islam Empiris.

Agama Islam masuk ke Kalimantan Selatan berlangsung secara perlahan tanpa paksaan dan tidak melalui proses peperangan, melainkan secara damai mulai di sekitar abad ke $14 \mathrm{M}$, sebelum berdiri kerajaan Banjar. Islam disebarkan melalui jalur perdagangan/ekonomi, mubaligh/ulama, politik dan tasawuf. Sarjana Belanda J. Mallinckrodt dalam bukunya yang berjudul "Het adatrecht van Bornoe" ( Hukum Adat di Kalimantan) jilid II diterbitkan di Leiden tahun 1928 menyebutkan bahwa di Kerajaan Banjar, pengislaman itu terjadi di

${ }^{1}$ Khadziq, Islam dan Budaya Lokal (Yogyakarta:Teras,2009), Cet.ke-1, 10-11. 
tahun 1540, pada masa Pangeran Samudera (Sultan Suriansyah) berkuasa. Keterangan tersebut didapatnya dari Hageman dalam TBG tahun 1857 halaman 239 dan dari Mayer dalam Indische tahun 1899 jilid I halaman $280 .^{2}$

Kerajaan Banjar berdiri tanggal 24 September 1526 M., bersamaan pengislaman raja dan para menteri kerajaan, dan agama Islam menjadi agama resmi kerajaan saat itu. Agama Islam ini disebarkan dengan bahasa Melayu, dengan menggunakan huruf Arab-Melayu, dipakai dalam kerajaan Banjar, dan para ulamapun dalam menyusun kitab menggunakan bahasa Melayu tersebut. ${ }^{3}$ Pada pertengahan abad ke 18 dan abad ke 19 perkembangan agama Islam di kerajaan Banjar semakin pesat. Hal ini ditandai dengan munculnya seorang ulama besar Banjar yang bernama Syekh Arsyad al-Banjari, dengan karya yang sangat terkenal yaitu kitab Sabilal Mubtadin. ${ }^{4}$

Walaupun masyarakat Banjar sudah lama menganut agama Islam, dan dipandang sebagai masyarakat yang agamis, namun dalam kenyataan masih ditemukan unsur-unsur yang tidak dapat begitu saja dianggap sebagai bersumber dari ajaran Islam. Dalam berbagai peristiwa kehidupan sehari-hari, banyak tradisi lokal yang bercampur dengan ajaran agama Islam. Percampuran antara agama dengan tradisi itu ternyata tidak mudah dihindari.

Pischer menyebutkan adanya "osmose" (percampuran) antara religi kerakyatan dengan religi yang didatangkan. Religi kerakyatan adalah keberagamaan yang tumbuh secara natural dalam kehidupan rakyat. Keberagamaan ini melekat bersama ajaran agama dalam kehidupan masyarakat yang menganut agama itu. Sinkretisme ini terjadi karena: (a) adanya pengakuaan secara tidak nyata kepada adanya otoritas yang menentukan susana kehidupan kini dan akan datang, (b) pengakuan itu mendasari cara kerja yang tidak memerlukan pengetahuan, hukum, sebab akibat yang lazim dalam dunia empiris, dan (c) legitimasi cara kerja dan perbuatan yang sebenarnya bertentangan dengan Islam. ${ }^{5}$

Dari sekian banyak tradisi yang masih dipertahankan masyarakat Banjar adalah dalam hal pencegahan atau penyembuhan penyakit dengan mengunakan jimat atau benda bertuah yang dipercaya mengandung kekuatan magis. Suatu penyakit yang tidak dapat disembuhkan dengan pengobatan modern, itu dianggap kena kapingitan yakni diganggu oleh makhluk gaib. Gejala kapingitan ini ialah berak darah, sakit kepala, sakit pinggang, alergi, bengkak, berbisul, bayi sering kencing dan menangis, penyakit di kemaluan, ini semua merupakan penyakit fisik. Selain itu, ada juga yang berupa penyakit batin berupa stres atau gangguan jiwa lainnya. ${ }^{6}$

${ }^{2}$ Ahmad Basuni, Nur Islam di Kalimantan Selatan: Sejarah Masuknya Islam di Kalimantan (Surabaya: PT. Bina Ilmu, 1986), Cet. ke- 1,10 .

${ }^{3}$ Sjarifuddin, et.al, Sejarah Banjar (Banjarmasin: Badan Penelitian dan Pengembangan Daerah Provinsi Kalimantan Selatan, 2004), cet. ke-2, 123.

${ }^{4}$ M. Suriansyah Ideham, et.al, Urang Banjar dan Kebudayaannya (Banjarmasin: Badan Penelitian dan Pengembangan Daerah Provinsi Kalimantan Selatan, 2005), cet. ke-1, 40.

${ }^{5}$ Nordiansyah, Sinkretisme (Banjarmasin: Fakultas Ushuluddin IAIN Antasari, 1982), 19-20.

${ }^{6}$ Tim, Agama dan Kemasyarakatan (Banjarmasin: PPPTA/IAIN Antasari 1982), 20. 
Ketika seseorang terkena musibah kesurupan atau kerasukan jin, serta penyakit fisik lainnya, maka cara penyembuhannya adalah dengan memberi jimat, berupa benda tertentu. Jimat ini adalah benda yang diyakini dapat menangkal, menyembuhkan berbagai gangguan penyakit lahir maupun penyakit non medis, dan bentuknya bermacam-macam.

Adapun benda-benda keramat yang dijadikan sebagai jimat tersebut di antaranya seperti: kain sarigading, caping, picis, sawan, samban, kuari, dan gelang buyu, keris, mandau, dan lain-lain. Benda-benda tersebut ada yang digantung di leher, diikat di kepala, di pinggang, dan dipakaikan pada badan, benda tersebut selalu dijaga, dibersihkan atau dirawat.

Kepercayaan dan perlakuan masyarakat Banjar tersebut tidak lenyap begitu saja walau masyarakat daerah ini dipandang sudah maju baik dari segi keberagamaan, pendidikan, ataupun ekonomi. Kehidupan masyarakat ini tidak terlepas dari pengaruh budaya atau adat-istiadat yang sudah melekat sebelum kedatangan Islam. Asimilasi dan akulturasi budaya tak terhindarkan pada Islam Banjar, sehingga tradisi yang mereka lakukan seakan-akan semua berasal dari Islam, tak terkecuali juga masalah penyembuhan secara irasional dengan menggunakan jimat tersebut. Keadaan tersebut membuat penulis ingin mengkaji lebih jauh terhadap tradisi Islam Banjar dalam mengobati suatu penyakit, baik penyakit batin maupun penyakit lahir, dengan menggunakan jimat sebagai sarana penyembuh.

Artikel ini merupakan hasil penelitian lapangan dalam bentuk studi kasus, yang berlokasi di daerah kabupaten Hulu Sungai Utara Provinsi Kalimantan Selatan. Daerah ini menjadi lokasi penelitian karena di daerah ini terdapat pembuatan kain sarigading yang merupakan benda bertuah, dan banyak pemakai bendabenda bertuah lainnya.

\section{Perlakuan Masyarakat Banjar Terhadap Jimat: Suatu Fenomena}

\section{Jimat sebagai Penolak Penyakit.}

Pemakaian jimat yang dimaksud adalah benda bertuah yang mengandung kekuatan gaib yang dapat menolak penyakit, dan dipakai oleh sebagian masyarakat Banjar. Dari hasil observasi dan wawancara, penulis mendapatkan data bahwa jimat-jimat atau benda-benda bertuah yang banyak beredar dan digunakan sebagai terapi terhadap penyakit oleh masyarakat Banjar diantaranya adalah kain sarigading, kalimbutuban, kuwari, caping, samban, gelang buyu, gelang sawan, baju berajah, cincin berajah dan gelang berajah, saputangan berajah, tempurung berajah, basal, gelang haikal, dan lain-lain.

Selanjutnya, berdasarkan hasil wawancara kepada para responden diketahui bahwa yang melatarbelakangi mereka menggunakan jimat sebagai sarana penyembuh penyakit adalah sebagai berikut: pertama, mereka adalah keturunan orang yang beranak kembar, dan salah satunya gaib (hilang) atau beranak orang gaib. Manusia tidak akan melahirkan jin, sebab lain jenis dan sebaliknya. Namun manusia bisa melahirkan orang gaib atau manusia yang digaibkan Allah. Orang gaib tersebut bisa terjadi waktu

${ }^{7}$ Abu Ayyash Rafa'alhaq, Buku Saku Ruqyah Kumpulan Doa-doa Ma'tsur Untuk. Mengobati Gunan-guna dan sibir (Jakarta: Tsabita Grafika 2010), 5 . 
dalam kandungan ibunya, ketika usianya sudah beberapa bulan kemudian menghilang, atau di saat dilahirkan dia menghilang, juga bisa terjadi di saat sudah dia besar kemudian menghilang dengan sendirinya. Sebagaimana manusia pada umumnya, orang gaib yang dewasa juga mereka saling kawin mengawini sesama orang gaib dan beranak pinak. Orang-orang yang memiliki hubungan kekerabatan dengan orang gaib inilah yang memiliki keharusan untuk memelihara dan memakai jimat atau benda bertuah seperti kain sarigading, samban kuwari, kalimbutuban dan sebagainya, bila memiliki penyakit yang sulit disembuhkan. ${ }^{8}$

Kedua, berdasarkan pengalaman lain pemakai jimat, mereka merasa sebagai juriat atau keturunan raja-raja Banjar zaman dahulu, baik dari kerajaan Dipa, Daha, ataupun kerajaan Banjar sendiri.' Ketiga, mereka mengaku keluarganya pemelihara buaya jelmaan, baik itu orang tuanya, kakeknya, datuknya, atau keluarga dekat lainnya yang memiliki dan memelihara buaya jelmaan tersebut. Maka ketika di antara keluarga mereka ada yang sakit dan susah disembuhkan. maka penggunaan jimat seperti kain sarigading, merupakan pilihan tepat dalam proses penyembuhan.

Kain sarigading merupakan jenis kain yang berbentuk baju, celana, sarung, laung, stagen, selendang, ataupun ayunan (buaian). Penggunaan kain ini sebagai alat terapi dari gangguan mahluk gaib, baik jin atau orang gaib. Gangguan mahluk gaib jenis ini dinamakan kapingitan. Seseorang dikatakan kena kapingitan apabila penyakit tersebut sudah diobati secara medis berulang-ulang, namun tidak ada hasilnya, dan bahkan bisa bertambah berat penyakitnya. Penyakit yang dirasakan akibat gangguan makhluk gaib ini bisa berupa alergi (gatal), bisul berkepanjangan, bengkak pada bagian tubuh tertentu tanpa sebab, sakit kepala pada saat-saat tertentu, sakit perut yang tak kunjung sembuh, sakit mata yang tidak terdeteksi penyebabnya secara kedokteran ataupun anak yang susah diatur (nakal) atau anak selalu menangis atau kencing pada malam waktu tidur padahal usianya sudah tua dan berbagai penyakit lainnya.

Pengguna kain sarigading ini tersebar di berbagai daerah. Kain sarigading dan benda bertuah lainnya ada dijual di daerah Hulu Sungai Utara, Hulu Sungai Tengah, Kabupaten Tapin, Kabupaten Banjar, Banjarmasin dan sampai ke daerah Kapuas. Sebelum dipakai, kain ini harus terlebih dahulu diukup/dirabun di atas dupa. Kain sarigading berupa sarung, baju, celana, buayan (ayunan) bisa dipakai baik laki-laki maupun perempuan. Tapi bentuk berupa stagen (babat), selendang hanya digunakan oleh penderita wanita ${ }^{10}$.

\section{Praktek Pemakaian Jimat dalam Masyarakat Banjar}

Kasus I. H. Imas menuturkan ketika masih anak-anak, dia merasakan sakit bila buang air kecil dan testis (buah zakar) selalu membesar seperti buah apel. Dia sudah hampir putus asa dalam berobat karena sudah banyak mantri yang telah mengobati, namun selalu tidak membuahkan hasil. Ketika ada orang yang

\footnotetext{
${ }^{8}$ Wawancara dengan Noor Saidah, pengrajin kain sarigading, Sungai Tabukan 20 September 2015 dan observasi.

${ }^{9}$ Wawancara dengan Sam'ah dan H. Imas, pengguna benda bertuah, Amuntai Tengah 24 September 2015 dan observasi.

${ }^{10}$ Wawancara dengan Hj. Hamnah, pengguna benda bertuah, 27 September 2015.
} 
mengatakan bahwa dia termasuk keturunan raja-raja candi Agung dan harus menggunakan kain sarigading sebagai terapi penyembuhan penyakit. Pada akhirnya, pakaian dari kain sarigading yang sudah lama tersimpan dalam lemari ibunya dipakaikan pada saya setelah dirabun/diukup dengan dupa yang dibakar juga ada air kembang di dekatnya, dan kain itu dipegang dan dikenakan dengan asap dupa yang dibakar tersebut. Dengan izin Allah ternyata saya sembuh dalam waktu yang tidak terlalu lama, setelah memakai pakaian dari kain sarigading tersebut ${ }^{11}$.

Kasus II. Masrudi mengaku keturunan dari raja-raja dari kerajaan Dipa Amuntai, sebab tokoh gaib yang bernama Pangeran Kacil pernah menemuinya dengan memberi laung dari kain Sarigading. Benda ini selalu disimpan dalam lemari dan dirabun/diukup satu tahun sekali. Pada suatu hari seluruh tubuhnya sakit dan matanya seperti mau keluar. Berbagai obat telah dimakan, namun tidak ada hasilnya. Pada suatu hari dia bertemu kawannya yang mengatakan bahwa Masrudi ini memelihara benda bertuah dalam rumah, dan benda ini harus dipakai. Menanggapi saran kawannya tersebut, dia mengeluarkan benda-benda bertuah (keris, Mandau, dan lain-lain) dari dalam kamarnya. Kawannya itu mengatakan bahwa semua benda tersebut bukan yang dimaksud sehingga meminta dicarikan benda lainnya. Masrudi kemudian mencari lagi dan menemukan laung dari kain sarigading yang merupakan pemberian dari tokoh gaib (Pangeran Kacil). Setelah dirabun/diukup dengan kemenyan, laung tersebut dipakai di kepalanya, seketika dia sembuh dari sakit dan matanya kembali normal. Masrudi mengaku sekarang memiliki beberapa jenis pakaian dari kain sarigading seperti laung, telaga darah berupa stagen, kain kuning yang bertuliskan kalimat syahadat. Ketiga benda ini merupakan pemberian langsung dari tokoh gaib yang disebut Pangeran Kacil. Lebih jauh diceritakannya bahwa dulu pada suatu hari temannya datang berkunjung ke rumahnya membawa seorang teman perempuan ketika berada di rumahnya, perempuan tersebut kesurupan, kemudian dipanggillah orang pintar untuk menolongnya. Sebelum orang pintar tersebut datang, kemudian Masrudi mengambil laung kain sarigading yang tersimpan dalam lemari dan menyentuhkan kain tersebut ke kepalanya. Anehnya seketika itu juga, orang tersebut sembuh dari kesurupan. ${ }^{12}$

Kasus III. Sam'ah memperkuat penjelasan Masrudi. Sam'ah menerangkan bahwa dia setiap malam Jumat menyediakan kopi pahit dan kopi manis serta kembang melati dan kenanga dalam rumahnya karena hal tersebut telah menjadi tradisi bagi keturunan Candi Agung. Sam'ah sering mengalami penyakit aneh, seperti tidak mau makan dan susah tidur selama beberapa bulan lamanya. Keadaan ini sering berulang-ulang, dan penyakit darah tinggi, serta sakit kepala berat merupakan kebiasaannya. Namun bila disediakan kopi pahit dan kopi manis serta kembang kenanga dan melati kemudian kain diukup/dirabun di atas kemenyan atau dupa yang dibakar, setelah itu langsung dipakaikan kain sarigading selengkapnya seperti selendang, baju, sarung, dan stagen, dan penggunaan kain ini tidak terus menerus, melainkan bila mau mandi atau shalat, maka pakaian itu dilepas sementara. Biasanya dalam waktu yang tidak lama, dia sembuh dari penyakit itu. Dia meyakini Allah yang menyembuhkan dan pakaian kain tersebut hanya

11 Wawancara dengan H.Imas, pemakai benda bertuah, HSU, 24 September 2015.

12 Wawancara dengan Masrudi, pemakai benda bertuah, 04 Oktober 2015. 
sebagai sarana media saja. Pakaian kain sarigading yang dimilikinya merupakan pemberian langsung dari makhluk gaib, yang datang kadang berwujud manusia dan kadang berbentuk naga yang menakutkan. Lebih jauh diungkapkannya bahwa pernah dua ekor naga hendak masuk ke rumahnya dengan lidah yang menjulur sehingga dia merasa ketakutan yang luar biasa. Kemudian naga itu berubah menjadi seorang lakilaki yang menyebut dirinya Pangeran Kacil, yang berbicara sebagaimana manusia pada umumnya. ${ }^{13}$

Kasus IV. Kurni menceritakan di saat usianya 17 tahun dia sakit alergi yang tak tersembuhkan dengan pengobatan secara medis, beberapa kali berobat ke mantri ternyata tidak sembuh, dan menggunakan ramuan pun tidak ada hasilnya, ada yang menyarankan agar dia memakai kain sarung sarigading. Setelah 7 hari memakai sarung kain sarigading ternyata tidak sembuh juga, padahal segala ketentuan untuk menggunakan kain ini sudah dipenuhi seperti diukup/dirabun. Hingga akhirnya diobati oleh seorang peruqyah sekaligus mantri. Dia gunakan terapi ruqyah dan di enjeksi kedua kakinya, dengan izin Allah saya sembuh dari penyakit itu setelah tiga hari penjalani terapi ruqyah dan enjeksi. Lebih jauh Kurni menceritakan tentang pengalamannya dalam menggunakan basal. Dia menceritakan di saat sekolah di SMAN Amuntai terjadi perkelahian antara siswa SMAN Amuntai yang berasal dari kelompok orang Alabio dengan siswa-siswa dari sekolah yang sama yang berlokasi di Amuntai Tengah. Siswa-siswa dari Amuntai Tengah menganggap Kurni termasuk geng dari Alabio, padahal bukan demikian. Pada tanggal 28 Oktober 1982 Kurni berangkat ke sekolah, dia mengetahui bahwa dirinya akan diserang oleh siswa-siswa dari Amuntai Tegah. Dia turun sekolah dengan menggunakan basal milik tentara yang pernah ikut perang di Irian Jaya. Basal tersebuat dipinjamnya dan diikatkan pada pinggang, dengan penuh tawakal mengharap perlindungan Allah, diapun berangkat ke sekolah. Di pagi yang sunyi di dalam kelas, tiba-tiba datang musuh-musuhnya akan menyerang dengan menggunakan besi panjang sekitar satu meter dan kayu balok yang siap akan memukulnya, namun di luar dugaan, kejadian anehpun terjadi ketika Kurni mengangkat kaki ke sebuah kursi, musuh-musuhnya tersungkur sebelum memukulnya, kemudian Kurni serta kawannya melompat di jendela dan langsung pulang. Keampuhan basal itu dirasakannya, dia mengatakan kekuatan pada basal ini merupakan kekuatan yang diberikan Allah ${ }^{14}$.

Kasus V. Hamnah mengaku bahwa dulu anaknya yang bernama Khairannor, ketika kecil, selalu menangis dan sangat susah dihentikan karena testis (buah zakar) semakin membesar dan terasa sakit. Sudah diobati baik secara medis maupun dengan cara pengobatan alternatif, namun hasilnya tidak ada. Pada suatu hari ada warga yang menyarankan agar memakai kalimbutuban/bubutuhan, sehingga suaminya pergi ke pasar untuk mencarinya hingga diperolehlah benda tersebut, yang kemudian dipakaikan kepada anaknya. Atas seizin Allah, dia akhirnya sembuh dari sakitnya testisnya seperti biasa dan tidak lagi penangisan. ${ }^{15}$

\footnotetext{
${ }^{13}$ Wawancara dengan Sam'ah, pemakai benda bertuah, 04 Oktober 2015.

${ }^{14}$ Wawancara dengan Kurni, pemakai benda bertuah, HSU, 23 September 2015.

${ }^{15}$ Wawancara dengan Hamnah, (orang tua Khairannor), 27 September 2015.
} 
Kasus VI. Keadaan yang sama juga diakui oleh Niah, di saat sepupunya yang bernama Bani juga sering menangis dan testis semakin hari semakin membesar, ibu dan keluarganya membantu agar dapat disembuhkan. Bani sudah dibawa berobat ke dokter namun belum ada hasilnya. Ada orang yang menyarankan agar dia memakai kalimbutuhan. Benda tersebut lalu dipinjam dari keluarganya kemudian digantungkan pada pinggang Bani (anak yang sakit). Anehnya tak berapa lama, anak tersebut sembuh dengan cepat. ${ }^{16}$

Kasus VII. Hj. Ikip punya pengalaman yang sama dan mengaku ketika anaknya yang berusia 3 tahun mengalami sakit alergi pada lehernya dan sudah diobati secara medis, namun tidak sembuh juga, akhirnya dianjurkan oleh neneknya agar mencari samban untuk digantungkan pada leher anaknya. Keinginan yang kuat agar anaknya dapat sembuh tersebut membuatnya menemui $\mathrm{Hj}$. Ida yang diketahuinya memiliki samban tersebut. $\mathrm{Hj}$. Ida bersedia menyerahkan samban miliknya dengan imbalan atau hadiah sepuluh gram emas dan kesepakatan terjadi. Setelah $\mathrm{Hj}$. Ikip memakaikan pakaian kalung samban tersebut kepada anaknya, penyakit alerginya mulai mengering, dan dalam waktu yang tidak lama sembuh tanpa menggunakan obat lain. Hj. Ikip juga merasa agak bingung kenapa bisa sembuh, namun dia tetap berkeyakinan Allah yang menyembuhkan sementara samban itu hanya sebagai sarana ${ }^{17}$

Kasus VIII. Mardiansyah. Anaknya yang bernama Siti hadijah selalu menangis dan sangat susah dihentikan. Kemudian dianjurkan oleh keluarga agar dipakaikan gelang sawan dan gelang buyu, dan ternyata menangisnya sudah sangat jarang terdengar. Dia juga membuatkan gelang jariangau agar anaknya tersebut tidak diganggu hantu baranak. Selanjutnya, ketika usia anaknya menginjak enam bulan, dia akan membuatkannya gelang dari kulit terenggiling, agar tidak balancat lehernya dan tidak baliyuran. Orang tua dulu mempercayai bahwa buyu adalah makhluk yang tidak kelihatan oleh pandangan manusia. Masyarakat hanya mengenal nama buyu saja, akan tetapi sangat sulit untuk memberi penjelasan tentang keberadaan dan bentuk buy u tersebut. Terjadi serangan atau isapan buyu pada anak bayi atau balita karena beberapa sebab, yaitu karena anak kena sinar atau cahaya lampu terlalu terang, dan karena suara orang-orang dewasa yang terlalu tinggi atau membuat kebisingan di dekat anak tersebut. Untuk mengatasi diberikannya gelang buyu oleh masyarakat. Lebih jauh dikatakannya bahwa ada istilah penyakit kerungkup, yaitu merupakan penyakit yang baabilis, dalam artian iblis yang mengganggu anak bayi, oleh karena itu disebut dengan penyakit bayi, karena kerungkup ini cenderung menyerang pada anak bayi saja. Untuk menangkalnya dipakaikan gelang kerungkup. Gelang kerungkup itu berasal dari buah kerungkup yang diikat dengan benang hitam. $^{18}$

Kasus IX. Ibus menuturkan bahwa picis dipercaya sebagai sarana untuk mengobati anak kecil yang selalu keluar air liur (baliuran). Ada kepercayaan dalam masyarakat bahwa jika anak kecil senantiasa keluar air liur terus menerus dari mulutnya, maka ini akibat dari ibunya yang mengandungnya sewaktu

\footnotetext{
${ }^{16}$ Wawancara dengan Niah, 26 September 2015.

${ }^{17}$ Wawancara dengan Hj. Ikip, HSU, 24 September 2015.

${ }^{18}$ Wawancara dengan Mardiansyah, pemakai benda bertuah, 21 September 2015.
} 
ingin makan (mangidam) sesuatu baik buah atau makanan lainnya tidak terpenuhi kehendaknya itu. Hal ini berakibat pada anaknya yang lahir akan baliuran. Untuk mengatasi anak yang baliuran itu, orang tuanya atau keluarganya akan mengalungkan picis di lehernya, dengan harapan terhindar dari baliuran tersebut. Selain benda tersebut ada lagi jimat atau benda bertuah lainnya yaitu sapu tangan barajah. Sapu tangan barajah ini, adalah suatu benda yang dipercaya memiliki kelebihan atau manfaat bila dipakai atau digunakan yakni sebagai berikut:

a. selamat dari segala musibah dan fitnah dari orang zalim.

b. akan disegani, dimuliakan banyak orang, dan dapat kepercayaan dari pimpinan.

c. segala hajat tercapai dan unggul dalam segala perkara.

d. mudah dalam mendapatkan rezeki.

e. selamat dari ilmu sihir dan gangguan setan.

f. cepat dapat jodoh.

g. bila diletakan di dalam rumah akan terhindar dari kebakaran dan kecurian. ${ }^{19}$

Kasus X. Hadijah seorang penjual tempurung barajah yakni kelapa yang dibelah dua dan ditulis wafaq di dalamnya yang dipercaya bila diisi air dan air tersebut diminum niscaya akan menyembuhkan penyakit singkogot atau sakit perut bagi wanita yang sedang haid (menstruasi). Singkogot adalah suatu penyakit yang bisa menyebabkan mandul atau tidak bisa punya anak. Menurut Hadijah, umumnya para wanita/isteri itu punya penyakit yang disebut singkogot, yakni sejenis binatang seperti cecak yang akan memakan sperma dalam rahim ibu yang menderita singkogot, sehingga tidak akan dapat hamil selama singkogot itu masih ada. ${ }^{20}$

Kasus XI. Sani memiliki jimat berupa cemeti yang dipercaya memiliki kekuatan gaib. Jika cemeti tersebut disimpan dalam rumah, insya Allah akan terhindar dari berbagai kejahatan, seperti kecurian, kerampokan, kebakaran dan gangguan mahluk jahat seperti guna-guna atau santet. Dan apabila dibawa dalam perjalanan, insya Allah berkat ayat-ayat Alquran di dalamnya akan terhindar dari berbagai kejahatan yang akan menerpanya. Kalau dipukulkan kepada penjahat, tidak jarang dia akan sakit keras bahkan bisa mengalami kematian. ${ }^{21}$

Kasus XII. Hj. Faridah menerangkan ketika anaknya yang bernama Norman mengalami penyakit aneh yaitu buah zakarnya semakin hari semakin membesar berbagai obat sudah diminumkan namun tidak juga sembuh. Nenek Norman menganjurkan untuk memakai samban di pinggangnya, dikarenakan keturunannya biasanya menggunakan samban ketika mengalami penyakit yang aneh. Setelah dipakaikan samban milik ibunya, anehnya penyakit Norman tersebut langsung menghilang ${ }^{22}$.

\footnotetext{
${ }^{19}$ Wawancara dengan Ibus, penjual benda bertuah, 26 September 2015.

${ }^{20}$ Wawancara dengan Hadijah, penjuah benda bertuah, 26 September 2015.

${ }^{21}$ Wawancara dengan Sani, penjual benda bertuah, 26 September 2015.

${ }^{22}$ Wawancara dengan Hj. Faridah (Mama Norman), 25 September 2015.
} 
Kasus XIII. Noor Saidah, seorang pengrajin kain sarigading menceritakan bahwa pekerjaannya membuat kain sarigading adalah pekerjaan yang dilakukan secara turun temurun mulai dari datu neneknya hingga dia. Pekerjaan ini merupakan mata pencaharian sehari-hari, walau penghasilan sebulan sangat sedikit, tapi pekerjaan menenun kain sarigading ini tidak bisa dihindari, karena keturunan. Lebih jauh diceritakannya bahwa banyak pengalaman aneh dalam pembuatan kain sarigading ini, di antaranya ialah pernah datang orang dari keturunan raja Kutai Kartanagara yang minta dibuatkan pakaian kain sarigading berupa sarung dan harus dibuatkan oleh tiga orang perawan, sementara anak Noor Saidah hanya dua orang perawan sehingga dia meminta wanita perawan lain ikut membantunya. Setelah uang dibayar lebih duluan sementara pakaian masih dalam proses pembuatan, si pembeli pulang ke daerahnya yang jauh, dengan kesepakatan bila barang sudah selesai dibuatkan nanti diberitahu dan akan di ambil oleh pembeli. Setelah semua pesanan selesai dibuat, kemudian dimasukan dalam lemari. Dalam waktu yang tidak lama dilihat kembali barang tersebut ke dalam lemari, ternyata barang tersebut sudah tidak ada lagi (hilang). Kemudian ditelpon si pembeli untuk diberitahu bahwa barang pesanannya hilang, ternyata si pembeli memberi tahu bahwa barang pesanannya telah datang dengan sendirinya, dan sudah dipakaikan kepada keluarganya yang sedang sakit. Ternyata dalam waktu yang tidak lama penyakit stresnya sembuh. Padahal sebelumnya oleh keluarganya yang si sakit itu sudah diobati ke banyak dokter dan orang pintar.

Pengalaman lain diceritakannya bahwa pernah datang orang minta buatkan celana dari kain sarigading karena buah zakarnyanya selalu membesar dan saran dokter harus dioperasi, namun keluarganya tidak mau karena penyakitnya dipandang tidak alami. Kemudian datang orang pintar memberitahu bahwa si sakit ini keturunan raja Kutai Kartanagara dan penyakitnya ini karena kapingitan, dan dikatakannya bahwa ada simpanan kain sarigading yang tidak terpelihara. Setelah dicari keluarganya dalam rumah ternyata barang pakaian tersebut berupa celana anak-anak ada dalam kis (peti basi), dan sudah rusak melekat dengan peti besi itu hingga akhirnya karena tidak bisa digunakan. Kemudian keluarga si sakit datang menemui Noor Saidah untuk dibuatkan pakaian dari kain sarigading. Kata Noor Saidah kalau memang keturunan raja dan cocok bila pakai kain sarigading, maka sediakan dulu piduduk yang terdiri beras, kelapa dan gula merah dalam rumah kamu dan lihat hasilnya nanti. Setelah dipenuhi dengan menyediakan piduduk tersebut ternyata penyakitnya mulai berkurang. Hal ini diberitahu kepada Noor Saidah dan langsung dibuat pakaian kain sarigading yang dikehendaki berupa celana dan bajunya yang dipakaikan pada malam Jumat setelah dirabun/diukup dengan dupa. Anehnya kata Saidah dari pengakuan keluarganya setelah dipakaikan celana dari kain sarigading itu seketika itu sembuh.

\section{Membaca Fenomena Pemakaian Jimat dengan Antropologi Agama}

Mencermati persoalan sekitar terapi yang dipraktikan sebagian masyarakar Banjar, dengan menggunakan jimat atau benda bertuah, dalam upaya penyembuhan penyakit, merupakan fenomena yang tidak dapat dipungkiri keberadaannya. Hal ini memang tidak terlepas dari fanatisme yang kuat terhadap naluri 
leluhur, dan pencetusan sikap yang serba magis mistis dan menjadi solusi yang dianggap tepat dalam menghadapi problema hidup.

Berdasarkan data dan fakta yang telah dijelaskan sebelumnya maka dapat diketahui beberapa hal berikut, yaitu pertama, mengenai aneka ragam jimat berupa benda bertuah. Kedua, mengenai latar belakang penggunaan jimat tersebut sebagai sarana penyembuhan penyakit. Ketiga, menyangkut sistem kepercayaan dan perlakuan masyarakat Banjar dalam penggunaan jimat atau benda bertuah untuk proses terapi penyakit.

Aneka ragam jimat sebagaimana diungkapkan sebelumnya adalah berwujud benda bertuah, sebagai sarana terapi seperti: kain sarigading, kalimbutuban/bubutuban, samban, caping, gelang buyu sawan, picis, sisik tenggiling, baju dan saputangan berajah, cincin, gelang, tempurung berajah, cemeti, basal. Pembicaraan tentang jimat dari benda bertuah, sering juga disebut dengan istilah "mana”. Dalam Kamus Antropologi dikatakan "mana” adalah suatu kekuatan gaib yang terdapat pada benda-benda tertentu dan bersifat impersonal, artinya tidak bersifat kemanusiaan. Biasanya dipergunakan sebagai jimat, yang membawa keberuntungan bagi pemiliknya, tetapi akan menimbulkan kerugian bila tidak menghiraukannya, menurut kepercayaan orang-orang murba. ${ }^{23}$

Mana dapat ditinjau dari berbagai segi, seperti arti, tempat dan manfaat. Dari segi arti mana adalah salah satu istilah lain dari apa yang disebut dinamisme. Dalam bahasa Inggris, kata tersebut berasal dari “dynamics' yaitu kepercayaan orang-orang murba yang beranggapan dalam beberapa benda hidup dan yang mati memiliki sifat luar biasa, yang bisa menimbulkan kebaikan dan kejelekan. Benda itu mereka anggap suci, yang dipercaya dapat memancarkan pengaruh baik atau jelek terhadap manusia dan dunia sekitarnya. ${ }^{24}$ Banyak nama dari istilah mana ini yang disesuaikan dengan daerah masing-masing, namun dalam istilah ilmu perbandingan agama atau antropologi benda yang mengandung tuah, hal tersebut disebut mana.

James E.O. menyebutkan bahwa mana adalah suatu istilah dari penduduk asli daerah Pasifik yang berarti kekuasaan gaib yang rahasia atau pengaruh yang mengikat benda-benda tertentu, kemudian menjadikan benda itu suci dan tabu. Leslie Spier menyatakan bahwa kebanyakan orang primitif percaya adanya suatu kekuatan gaib yang lain dari roh dan dewa-dewa. Dalam bentuknya yang kuno, orang Melanesia mempercayai mana sebagai sumber segala kekuatan dan dasar segala tindakan manusia. Dengan demikian dapat dipahami bahwa mana itu adalah kekuatan yang bersifat gaib, mengatasi kekuatan lahir, suci, mengandung khasiat baik, juga buruk menurut keperluan dan menguasai kehidupan manusia penganutnya, yang menggunakannya sebagai jimat.

Dari segi tempat, mana sebagai suatu kekuatan, dan baru akan nyata kuasanya atau kekuatannya itu, kalau sudah jelas di mana atau pada tempat apa ia berada. Pada hakikatnya, tidak ada mana yang terlepas dari ikatan tempat hinggap. Semua benda baik nyata maupun abstrak bisa menjadi ketempatan mana. Benda nyata baik berupa mahluk hidup seperti manusia dan binatang, maupun benda mati seperti batu, kayu, besi dan lain sebagainya bisa dianggap memiliki mana. Begitu juga benda abstrak seperti situasi atau suasana, roh dan lain

${ }^{23}$ Ariyono Suyono, Kamus Antropologi (Jakarta, Akademika Pressindo, 1985), 238.

${ }^{24}$ Ariyono Suyono, Kamus Antropologi, 95. 
sebagainya, sama juga dengan gejala alam seperti kilat, halilintar, badai dan sejenisnya, sering dianggap sebagai mengandung mana.

Adapun dari segi manfaat, bahwa mana mempunyai sifat-sifat: kuat, tidak dapat dilihat, tidak mempunyai tempat tetap, tidak mesti baik dan tidak pula mesti buruk, kadang-kadang dapat dikontrol dan biasanya tidak. Sesuai dengan maknanya; kekuatan, daya, khasiat, keramat, tuah, maka sudah pasti bahwa ia bermanfaat bagi manusia. ${ }^{25}$ Terhadap benda yang mengandung mana, manusia harus bersikap hati-hati dan awas agar benda tersebut tidak berubah menjadi merugikan. Sikap awas yang diambil oleh manusia primitif terhadap segala yang mengandung mana, dinyatakan dengan perkataan tabu. Kalau sesuatu dikatakan "tabu" itu maksudnya hampir serupa dengan "awaslah"! sangat berbahaya!. Manusia dan benda manusia dapat "tabu" untuk sementara waktu, umpamanya seseorang harus berhati-hati, misalnya seorang perempuan hamil tentu banyak pantangan. Barang siapa melangggar tabu, iapun akan memikul akibat dari pelanggaran itu. ${ }^{26}$

Responden pengrajin kain sarigading menuturkan bahwa kebanyakan pengguna jimat dari benda bertuah untuk mengatasi penyakit beranggapan bahwa mereka menggunakan benda bertuah sebagai jimat untuk terapi karena ada keluarga atau kerabat dekatnya lahir dalam keadaan kembar, namun salah seorang menghilang atau gaib. Hal ini bisa terjadi pada dirinya, saudara atau orang tuanya maupun keluarga atau kerabat dekatnya yang merasakan ada kembarannya yang gaib atau menghilang. Orang Banjar umumnya menyebutnya saudara kembar yang gaib itu dengan istilah orang Gaib/orang halus. Dia bukan jin, sebab manusia tidak akan melahirkan jin dan sebaliknya. Adapun responden lain mengakui bahwa menggunakan jimat sebagai sarana pengobatan dikarenakan keluarga dekatnya memelihara buaya jelmaan. Ketika anak cucunya mengalami penyakit yang susah disembuhkan secara medis, maka memakai jimat menjadi suatu keharusan. Ada juga responden yang mengaku bahwa menggunakan jimat untuk pengobatan dilatarbelakangi karena dirinya merupakan keturunan dari raja-raja pada zaman dahulu.

Berkenaan dengan latarbelakang pemakaian jimat yang dikaitkan adanya hubungan dengan orang gaib, buaya jelmaan dan keturunan raja-raja, memang diakui secara umum oleh masyarakat Banjar. Di antara tokoh-tokoh jenis makhluk halus yang terkemuka adalah tokoh raja-raja Banjar yang mitologis, khususnya dari zaman kerajaan sebelum Islam, tetapi ada juga tokoh dari zaman permulaan Islam. Sampai saat ini masih ada orang yang wafat, menjadi orang gaib. Selain menjadi orang gaib, konon ada pula tokoh dari zaman dulu yang menjelma menjadi naga atau buaya yang masih hidup dalam air hingga sekarang. Alam gaib adalah tempat orang-orang gaib hidup bermasyarakat. Alam gaib ini adalah berada di sekeliling kita, namun tidak tampak keberadaannya. Demikian juga beberapa bukit, antara lain gunung Pamatoan dan gunung Candi Agung, dikenal masyarakat sebagai (lokasi) keraton masyarakat gaib, tanah rawa tertentu, antara lain Pinang Habang di sekitar muara Batang Alai merupakan juga lokasi perkampungan orang gaib tersebut, dan pohon kayu tertentu juga terkadang dicurigai sebagai gedung megah milik tokoh terkemukan dari orang gaib, serta di samping rumah apakah sungai atau lainnya terkadang diduga sebagai jalan orang gaib.

25PPPTA, Perbandingan Agama I (Jakarta, Direktorat PPTAI 1981/1982), 89-102.

${ }^{26}$ A.G. Honig, Ilmu Agama I (Jakarta, Kristen, 1959), 30. 
Berbagai penyakit seperti kesurupan atau penyakit lain yang susah disembuhkan secara medis, terkadang dukun maupun tabib mengatakan ada kaitannya dengan tokoh gaib tertentu misalnya dihubungkan dengan Pangeran Suryanata, Putri Junjung Buih, kesurupan atau kesarungan datuk Baduk, dan lain-lain. Upacara sesaji harus dilakukan setahun sekali, dilaksanakan pada aruh tahun, menyanggar dan bapalas padang, atau sewaktu-waktu kapanpun diperlukan. Ada banyak tabu yang harus diperhatikan, misalnya keengganan sopir membawa penumpang yang membawa nasi ketan, lemang, telor rebus, karena khawatir akan terjadi kecelakaan bila membawa makanan orang gaib tersebut. Di kalangan kelompok orang-orang tertentu merasa punya silsilah dengan raja-raja atau pada kelompok tertentu percaya ada di antara nenek moyangnya yang gaib dan hidup selaku orang gaib sampai sekarang, atau telah menjelma menjadi naga dan buaya. ${ }^{27}$

Kepercayaan terhadap nenek moyang mereka yang dikaitkan dengan binatang, merupakan suatu paham totem. Kata totem diambil dari Ojibwa, suatu masyarakat Algonquin Kanada. Ungkapan atoteman berarti “dia adalah keluargaku”. Klan-klan Ojibwa diberi nama berdasar spesies-spesies binatang, sehingga orang-orang mungkin mengatakan makna nintotem: "saya adalah beruang". Peneliti-peneliti selanjutnya menggunakan istilah totemisme untuk menyebut fenomena serupa yang terdapat di tempat lain dan kemudian digunakan sebagai suatu konsep general yang mengacu kepada berbagai situasi dimana dianggap terjadi hubungan khusus antara kelompok sosial dan tumbuhan. Seringkali hubungan itu dalam bentuk ritual, dimana binatang tertentu dianggap suci dan memiliki kekuatan gaib, terdapat tabu-tabu tertentu yang terkait dengan binatang dan anggota kelompok, bahkan mereka meyakini bahwa dirinya adalah keturunan spesies-spesies totemik. $^{28}$

Sama seperti 'mana', maka totem dan tabu banyak diambil alih dan digunakan oleh para sarjana dalam konteks yang lebih luas lagi. Keduanya, baik totem maupun tabu, mempunyai dimensi sosial maupun ritual. Aspek atau dimensi sosial dari totem dan tabu terlihat pada sikap-sikap tertentu terhadap kekerabatan darah dan juga dalam aturan-aturan perkawinan dan turunan. ${ }^{29}$ Pendapat lain menerangkan bahwa kata totemis ditulis secara beragam. Totem, tatam, dodaim dimaknai sebagai roh pelindung manusia yang berwujud binatang. Totemisme dapat dibedakan atas; totemisme perseorangan, dimana seekor binatang menjadi pelindung orang tertentu, dan totemisme golongan, di mana jenis binatang tertentu dianggap mempunyai hubungan dekat dengan suatu golongan atau suku bangsa tertentu. Totemisme merupakan fenomena yang menunjukkan kepada hubungan organisasional khusus antara suatu suku bangsa dan suatu spesies tertentu dalam wilayah binatang. Hubungan ini terlihat dalam upacara-upacara khusus dan sebagian lagi dalam aturan-aturan khusus perkawinan di luar suku.

Totemisme merupakan fenomena yang sangat beraneka ragam dan luwes. Hal ini dapat digambarkan sebagai suatu sistem kepercayaan dan perlakuan yang mewujudkan hubungan mistik atau ritual antara anggota kelompok sosial dan suatu jenis binatang. Fenomena tersebut mengandung perintah-perintah yang dijunjung

${ }^{27}$ Alfani Daud, Islam dan Masyarakat Banjar (Jakarta, PT. RajaGrafindo Persada, 1977), 582.

${ }^{28}$ Brian Morris, Antropologi Agama (Yogyakarta, AK Group, 2003), 338.

${ }^{29}$ PPPTA, Perbandingan Agama I, (Jakarata, Dir. Pembinaan PTAI, 1983) hal 57. 
tinggi, seperti larangan membunuh, mengganggu atau makan daging binatang totem. Para penganut kepercayaan totemisme meyakini bahwa mereka diturunkan dari satu leluhur totem yang mistis, atau bahwa mereka dan para anggota dari totem sejenis merupakan "saudara". Mereka menggunakan totem sebagai simbol kelompok dan menganggapnya sebagai "pelindung” kelompok secara keseluruhan. Masalah pokok dalam totemisme ialah adanya persekutuan, partisipasi dan saling menjadi bagian antara manusia dan binatang. Kesucian mereka hanyalah sekunder; yang lebih penting adalah lukisan makhluk-makhluk pada kayu dan batu. Pengelompokan masyarakat mereka dianggap suci dan karena itu totem mereka pun dianggap suci.

Rasa hormat akan binatang-binatang totem diungkapkan dalam hubungan antara anggota-anggota individual dengan masyarakat itu sendiri dan menjadi sumber dari tradisi moral dan makanan mereka. Para dewa suku-suku bangsa mungkin mewakili keadaan masyarakat suku tersebut. Dalam arti tertentu, keberadaan totem memperlihatkan kehidupan masyarakat itu sendiri, dimana terkadang para anggotanya memandang diri mereka sebagai diturunkan dari totem. Dalam tindakan dan upacara totem, kepentingan religius yang paling utama adalah pengaktualisasian identitas antara totem dan kelompok. Dalam upacara-upacara ini tanda totem dilukiskan pada tubuh, atau tari-tarian dilakukan dalam bentuk tanda totem. Pada umumnya tato adalah ciri totem dan suku-suku Indian Amerika menghiasi diri mereka dengan bagian-bagian dari binatang totem, misalnya bulu-bulu sebagai hiasan kepala.

Pada suku tertentu hubungan rahasia antara manusia dan binatang tadi diakui sebagai hubungan keagamaan. Dari sini dapat diduga bahwa tidak jarang manusia menganggap binatang-binatang tertentu sebagai nenek moyangnya, hidupnya dekat binatang tersebut, dan dengan itu manusia beranggapan dapat memperoleh daya kekuatan yang magis. Atau dengan kata lain, manusia dapat memperoleh keselamatan dari perhubungannya dengan binatang. ${ }^{30}$

Hubungan kekerabatan dan kekeluargaan dengan binatang seperti buaya, merupakan sesuatu bersifat totemisme. Penganut paham ini memperlihatkan adanya sikap-sikap khusus terhadap binatang tersebut seperti sikap kagum, tertarik, dan rasa takut serta cemas, karena binatang itu diakui memiliki hubungan yang erat dengan kehidupan manusia. Malah sering meningkat kepada pengakuan bahwa binatang tersebut nenek moyang atau leluhurnya. Pemujaan terhadap arwah leluhur seringkali melibatkan kepercayaan bahwa semua anggota suatu suku adalah keturunan dari seorang (tokoh) tertentu yang selain itu juga diyakini bentuk seekor binatang atau makhluk hidup lainnya. Karena itu nampak adanya hubungan-hubungan tertentu pada pertalian darah, kekerabatan dan keturunan.

Taylor mengutip dari Wilken tentang masalah buaya-buaya yang dianggap baik dan bersahabat dengan manusia yang baik, dan menjadi pelindung mereka. Buaya-buaya ini dapat membunuh siapa saja yang dianggap sebagai musuhnya. Persembahan korban selalu dilakukan terhadap buaya itu dan orang berusaha mencari berkah.

Keadaan yang mendasar dalam totemisme ialah adanya persekutuan, partisipasi dan saling menjadi bagian antara manusia dan binatang. Dalam persekutuan itu manusia primitif percaya bahwa ia akan 
memperoleh kekuatan yang luar biasa. Totemisme erat sekali hubungannya dengan animisme, karena dalam totemisme binatang-binatang tertentu kadang-kadang dianggap sebagai nenek moyang suku, yaitu sebagai nenek moyang azali.

Menurut Durkheim, totemisme merupakan semacam Tuhan yang tidak bersifat kemanusiaan, yang menetap di bumi dan bersenyawa dengan benda-benda yang tak terbatas jumlahnya, dan erat hubunganya dengan 'mana' dan ide yang sejenis dengan masyarakat primitif. Tetapi di Australia, kenyataanya penduduk asli beranggapan bahwa ide Tuhan tersebut tidak dalam bentuk yang abstrak, melainkan dalam bentuk binatang dan tumbuh-tumbuhan, yaitu totem, yang merupakan "bentuk materiil" yang dibelakangnya terdapat imajinasi yang menggambarkan zat bukan materiil atau Tuhan. Karena itu yang prinsip dan vital bagi mereka adalah "manusia dan totemnya".

Totem disamping merupakan simbol Tuhan atau sesuatu yang vital juga menjadi simbol masyarakat, karena Tuhan dan masyarakat adalah identik. Tuhan dan klan yang menjadi prinsip totemisme, diwujudkan dan digambarkan dalam bentuk yang dapat dilihat, yaitu pada binatang atau tumbuh-tumbuhan yang bertindak selaku totem. Dalam simbol totem inilah para anggota klan memperlihatkan sikap moral dan rasa ketergantungannya satu sama lain, jika terhadap kelompoknya secara keseluruhan. Dengan itu pula mereka berkomunikasi dan menegakkan solidaritas. Demikianlah penelitian Durkheim tentang totemisme di Australia.

Para sarjana agama menganggap totemisme hanyalah merupakan ekspresi keagamaan dalam pemujaan dan penyembahan terhadap binatang. Totem dapat dibedakan atas totemisme perorangan dimana seekor binatang menjadi pelindung orang tertentu, dan totemisme golongan atau suku di mana jenis binatang tertentu dianggap dekat hubungannya dengan suatu suku / golongan tertentu dan menjadi pelindung mereka. ${ }^{31}$ Dengan demikian sebagian masyarakat Banjar yang beranggapan bahwa ada hubungan kekerabatan dengan buaya jelmaan, di mana pemikiran semacam ini merupakan suatu faham totem.

Selanjutnya, terkait sistem kepercayaan dan perlakuan masyarakat Banjar dalam penggunaan jimat berupa benda bertuah untuk terapi, semua responden mengaku dan mempercayai ketika dihadapkan kepada penyakit yang tidak tersembuhkan secara medis, lahirlah sebuah pemikiran bahwa penyakit tersebut tidak alami karena tidak masuk akal, dan dipercaya ada keterkaitan dengan yang gaib, sehingga dilakukan terapi secara magis. Hal itu sesuai dengan apa yang dikemukakan Frazer bahwa manusia memecahkan soal-soal hidup dengan akal dan sistem pengetahuannya. Tetapi akal dan sistem pengetahuannya ada batasnya. Sehingga semakin terkebelakang kebudayaan manusia, sehingga semakin sempit lingkaran batas akalnya.

Persoalan hidup yang tak mampu terpecahkan dengan akal pikiran, sehingga persoalan tersebut dipecahkan secara magic, ilmu gaib. Manusia mulanya hanya mempergunakan ilmu gaib untuk memecahkan soal-soal hidupnya yang ada di luar batas kemampuan dan pengetahuan akalnya. Pada waktu itu religi belum ada dalam kebudayaan manusia. Lambat laun dirasakan banyak dari perbuatan magic itu tadi tidak ada hasilnya, 
maka mulailah ia yakin bahwa alam didiami oleh makhluk-makhluk halus yang lebih berkuasa daripadanya, lalu mulailah ia mencari hubungan dengan makhluk-makhluk halus itu. Dengan demikian timbullah religi.

Menurut Frazer, memang ada perbedaan besar antar ilmu gaib dan religi. Ilmu gaib adalah segala sistem tingkah laku dan sikap manusia untuk mencapai suatu maksud dengan menguasai dan mempergunakan kekuatan-kekuatan dan kaidah gaib yang ada di dalam alam. Sebaliknya religi adalah segala sistem tingkah laku manusia untuk mencapai suatu maksud dengan cara menyandarkan diri kepada kemauan dan kekuatan makhluk-makhluk halus seperti roh-roh, dewa-dewa, tokoh tokoh gaib yang menempati alam. ${ }^{32}$

Benda-benda bertuah yang dianggap memiliki kekuatan gaib, yang oleh sebagian masyarakat Banjar diakui dapat dijadikan benteng dan sarana terapi berbagai penyakit. Sehingga benda-benda tersebut dipakai dan dijadikan sebagai jimat. Pemahaman benda sebagai jimat ini dalam dunia antropologi atau pada ilmu perbandingan agama bisa disebut juga dengan istilah fetishisme.

Fetish adalah suatu istilah yang diambil dari Bahasa Portugis yaitu "feitico" yang berarti jimat atau digunakan sebagai penangkal yang kemudian diterapkan juga kepada pustaka atau peninggalan, yaitu sesuatu yang mengandung daya atau benda-benda itu biasanya dianggap mempunyai tuah atau mana, atau kesaktian ${ }^{33}$. Istilah dalam bahasa Latin disebut fectitius, yaitu suatu yang disihir atau dibaca mantra kepada suatu benda, misalnya batu atau akar pohon atau suatu benda lainnya yang mempunyai bentuk aneh yang dianggap mempunyai kekuatan atas alamiahdan mempunyai roh $^{34}$.

Benda-benda bertuah yang diperlakukan sebagian masyarakat Banjar sebagai jimat, baik berupa samban, kuwari, kalimbutuban, kain sarigading, basal, baju atau sapu tangan barajah yang sudah tentu benda tersebut telah diisi dengan kekuatan gaib berupa bacaan atau tulisan tertentu. Sebagian jimat ada yang diukup atau dirabun dengan kemenyan yang dibakar dan asapnya dikenakan pada benda bertuah atau jimat pada waktu tertentu dengan ada kembang, dan ini merupakan suatu pemujaan. Karena benda-benda yang mengandung fetish dipuja, maka benda-benda tersebut diperlakukan dengan sangat hati-hati, ini dimaksudkan untuk menjaga kesucian dan kekeramatannya yang mendatangkan kebaikan dan dimaksudkan juga untuk menghindari akibat buruk yang bisa ditimbulkan dari pengaruhnya.

Maka fetishisme adalah pemujaan terhadap benda-benda, yang mana benda-benda tersebut mempunyai tuah yang ampuh. Selain itu benda yang dianggap bertuah tersebut pun sering dibawa kemana-mana, ditaruh di dalam kantong, atau diikat dengan benang yang ditaruh di leher atau digantungkan di depan pintu rumah, bahkan ada yang tidak memperbolehkan untuk dipegang atau dijamah. Semua itu dimaksudkan bahwa dengan adanya benda atau fetish tersebut supaya bisa menolong mereka dari marabahaya dan diharapkan dapat menyelamatkannya.

\footnotetext{
${ }^{32}$ Koentjaraningrat, Sejarah Teori antropologi I (Jakarta: UI Press, 1987), 54.

${ }^{33}$ A. G. Honig Jr., Ilmu Agama I (Yogyakarta: Gunung Mulia, 1994), 38.

${ }^{34}$ Ariyono Suyono, Antropologi Agama (Jakarta: Akademika Pressindo, 1985) 121.
} 


\section{Penutup}

Sebagian masyarakat Banjar menggunakan jimat berupa benda bertuah, untuk pembentengan dan penyembuhan penyakit. Adapun jimat-jimat tersebut di antaranya ialah: kain sarigading, kalimbutuban, kumari, caping, samban, gelang buyu, gelang sawan, baju berajah, cincin berajah dan gelang berajah, saputangan berajah, tempurung berajah, gelang haikal, basal.

Masyarakat Banjar yang memakai jimat, beranggapan bahwa yang melatarbelakangi mereka harus memakai jimat tersebut untuk pembentengan atau penyembuhan penyakit adalah: 1). Mereka merasa mempunyai hubungan keluarga/berkerabat dengan orang gaib. Hal ini terjadi bisa dia, saudara atau orang tuanya maupun nenek moyangnya yang memiliki saudara kembar dengan orang gaib atau orang yang di gaibkan Tuhan. 2). Mereka beranggapan bahwa leluhurnya mempunyai hubungan kekeluargaan/kekerabatan dengan makhluk gaib yang menjelma kepada binatang buaya. 3). Mereka merasa juriat atau keturunan dari rajaraja pada zaman dahulu.

Para responden mempercayai bahwa ketika mereka mengalami suatu penyakit yang tidak dapat teratasi dengan pengobatan secara medis atau kedokteran. Maka hal ini ada kaitannya dengan dunia magis. Maka solusinya melalui pengobatan magis, yakni memakai jimat. Jimat itu ada yang dipakai di kepala, leher, bahu, pinggang maupun dipakai di badan berupa baju dan celana.

Kepercayaan dan perlakuan sebagian masyarakat Banjar terhadap jimat dalam mengatasi problema, merupakan suatu mencetusan sikap hidup yang serba magis mistis, serta fanatisme yang kuat terhadap naluri leluri leluhur. Jimat atau benda bertuah dalam kepercayaan masyarakat Banjar tersebut, sangat berhubungan pembahasannya dengan istilah mana, dinamisme, animisme, fetisisme dan totemisme dalam kajian antropologi.

Alangkah indahnya sekiranya masyarakat Islam di Kalimantan Selatan ini mengamalkan wiridanwiridan tertentu secara rutin atau selalu mewajibkan amalan-amalan sunat untuk dirinya sendiri, sehingga keadaan ini akan menjadi benteng atau pagar gaib bagi dirinya. Maka dengan demikian berbagai pengaruh jahat dari dunia gaib akan terhalang untuk mengganggunya, dan akan terhindar dari berbagai penyakit yang susah disembuhkan secara medis. Kajian masalah penggunaan jimat oleh sebagian masyarakat Banjar ini perlu diteruskan, melalui pendekatan analisis agama, maupun dalam tinjauan psikologis []

\section{DAFTAR PUSTAKA}

Ahmadi, Abu. Perbandingan Agama. Semarang: Bulan Bintang. 1973. 1986.

Antropologi Budaya (Mengenal Kebudayaan dan Suku-Suku Bangsa di Indonesia). Surabaya: Pelangi.

Basuni, Ahmad. Nur Islam di Kalimantan Selatan: Sejarah Masuknya Islam di Kalimantan. Surabaya: PT. Bina Ilmu. 1986.

Daud, Alfani. Islam dan Masyarakat Banjar. Jakarta: PT. RajaGrafindo Persada. 1977.

Departemen P dan K. Kamus Besar Bahasa Indonesia. Jakarta: Balai Pustaka. 1990. 
Gani, Fathuddin Abdul. Perbandingan Agama. Yogyakarta: t.p. 1991.

Honig Jr., A. G. Ilmu Agama I. Yogyakarta: Gunung Mulia. 1994.

Ideham, M. Suriansyah. et.al. Urang Banjar dan Kebudayaannya. Banjarmasin: Badan Penelitian dan Pengembangan Daerah Provinsi Kalimantan Selatan. 2005.

Khadziq. Islam dan Budaya Lokal. Yogyakarta: Teras. 2009.

Koentjaraningrat. Metode Antropologi. Jakarta: Universitas Indonesia Pers. 1958. Sejarah Teori Antropologi I. Jakarta: Universitas Indonesia Press. 1987.

Manaf, Mudjahid Abdul. Ilmu Perbandingan Agama. Jakarta: Raja Grafindo Persada. 1994.

Manan, Imbran A. Pelbagai Taubid Populer. Surabaya: PT Bina Ilmu. 1982.

Morris, Brian. Antropologi Agama: Kritik Teori-teori agama Kontempurer. Yogyakarta: AK Group. 2003.

Nasution, Harun. Islam Ditinjau dari Berbagai Aspeknya. Jilid I. Jakarta: Bulan Bintang. 1974.

Noerman, Mohd. Aliran-Aliran Kepercayaan dan Agama-Agama Besar di Dunia. Jakarta: Mutiara. 1975.

Nordiansyah. Sinkretisme. Banjarmasin: Fakultas Ushuluddin IAIN Antasari. 1982.

PPPTA. Perbandingan Agama I. Jakarta: DPPTAI. 1982.

Rafa'alhaq, Abu Ayyash. Buku Saku Ruqyah Kumpulan Doa-doa Ma'tsur Untuk Mengobati Gunan-guna dan sibir. Jakarta: Tsabita Grafika. 2010.

Sjarifuddin. et.al. Sejarah Banjar. Banjarmasin: Badan Penelitian dan Pengembangan Daerah Provinsi Kalimantan Selatan. 2004.

Suyono, Ariyono. Kamus Antropologi. Jakarta: Akademika Pressindi.

Tim. Agama dan Kemasyarakatan. Banjarmasin: PPPTA/IAIN Antasari. 1982. 